\section{Does the Structure of the Board of Directors Improve M\&A Performance?}

\author{
Aleksandra Anna Chadam \\ Duff E Phelps, the Netherlands \\ aleksandra.chadam@gmail.com \\ https://orcid.org/0000-0003-1184-9504
}

\author{
Does the \\ Structure \\ of the Board \\ of Directors \\ Improve M\&A \\ Performance?
}

\begin{abstract}
Purpose - The research focuses on examining which characteristics can raise or diminish board effectiveness in the context of M\&A activities of companies.

Design/Methodology/Approach - The nature of the research was quantitative, and the sample was selected purposefully. The data was retrieved from four databases: Thomson One, Eventus, Institutional Shareholder Platform (ISS) and Compustat. The final sample consisted of 2,613 mergers and acquisitions and was selected by applying the following criteria: both the bidder and the target are US-based companies, the acquirer was a listed company, the acquisition announcement took place over the period 2008-2017, the deal value exceeded USD 1 million, the transaction resulted in a control gain over the target company. M\&A performance was assessed using cumulative abnormal return (CAR) method, while the board influence was examined using ordinary least square (OLS) regression. Five hypotheses regarding the influence of board independence, gender diversity, size, CEO duality and type of elections were tested in the research. Findings - Two out of five hypotheses were confirmed in the study. Board independence and board classification increase bidders' CARs over the deal announcement period.

Research limitations/implications - The main limitation is related to the measurement of M\&A performance, which is very difficult to quantify. Moreover, the method of selection of the sample, especially a higher proportion of companies from certain industries could affect the outcomes and underestimate the impact of gender diversity. Further research could investigate the deals in the long-term perspective and apply different criteria in the sample selection process. Practical implications - The outcome of this study is of importance to acquisitive and nonacquisitive companies by aiding them in finding an optimal board structure, which can effectively monitor and motivate the CEO, leading to profitable decisions concerning not only M\&A but all major investments.

Originality/Value - The study investigates the topic of board effectiveness in the M\&A context, whose research coverage is still very limited. The study covers five board characteristics and several control variables to increase the robustness of the results and ensure their correct interpretation. Finally, the sample consists of the most recent data, which enables to draw upto-date conclusions that consider constantly developing corporate governance law and trends regarding the board structure and composition.
\end{abstract}

Category - Research paper.

Keywords - M\&A, M\&A performance, board effectiveness, board independence, gender diversity, board size, CEO duality, classified board

\section{Syinergia}

International Journal of Synergy and Research

Vol. 7, 2018

pp. 15-31 


\section{Introduction}

The primary purpose of business is value creation for the owners of the company. Mergers and acquisitions are a common path for managers to rapidly expand the business, profit from synergy effects and, as a result, improve the firm's performance and increase its value. However, research shows the average dollar change in the bidder shareholders' wealth, when the acquisition announcement is made, is negative, which represents a negative net present value of the merger (Malatesta, 1983; Moeller et al., 2004). Destruction of company value as a result of M\&A investments might be assigned to unreasonably elevated expectations of synergy effects and thus inflated valuations, an insufficient due diligence of the target company or undervaluation of potential obstacles in the post-acquisition integration process (Bruner, 2004). Such mistakes may arise due to the agency and behavioural problems in the acquiring company: empire-building desires or overconfidence of the CEO (Jensen and Meckling, 1976; Jensen, 1986; Malmendier and Tate, 2008). In business practice, corporate governance mechanisms work as a tool to limit agency and behavioural problems and to prevent value-destroying acquisitions. One of them is a board of directors, which carries monitor management and vote on major decisions including entering mergers and acquisitions.

Numerous studies find evidence that some features of the board: independence, board size, gender diversity, CEO duality and the types of elections, can raise the board's control effectiveness. An effective board will not authorize value-destroying acquisitions arising from non-economic reasons. Thus, the presence of an effective board should positively affect M\&A performance.

The study attempts to identify board characteristics that affect M\&A performance measured as a market response (abnormal returns) over the announcement period and is based on a sample of 2,613 deals. Since the unitary board enables for more freedom in designing the board structure and thus larger variety among the companies (for instance, duality of CEO), the research covers US companies and their boards.

The research shows board independence has a significant and positive influence on the acquirer abnormal returns during the announcement period. The results are consistent with the theory that more independent boards monitor managers better, decrease managerial entrenchment and limit pursuing value-destroying acquisitions. Further, a classified board significantly and positively influences bidders CAR. This is consistent with the theory that a classified board reduces a takeover pressure and encourages managers to pursue deals that create value in a long-term perspective. No evidence for a statistically significant impact of gender diversity, board size and CEO duality on M\&A performance is found.

\section{Literature review}

\subsection{Motives behind M\&A transactions}

Mergers and acquisitions may create a value. However, the reasons behind pursuing a deal have to be rational and economic: potential synergy effects, profiting from intellectual capital or diversification. However, in business reality deals are motivated by agency issues and behavioural biases. According to agency theory, managers have 
personal incentives to increase their power and compensation and they may grow the company beyond the optimal size (Jensen, 1986). Since mergers and acquisitions are a fast way to expand a business in comparison to internal growth, they might serve as a tool to "build an empire". Moreover, managers may be incentivized to undertake risky acquisitions by a convex payoff structure of their compensation package and bonuses following the transaction. According to hubris theory of Roll (1986), managers acquire companies, because they believe that they possess superior managerial skills and that the target company will be worth more under their control. As a result, they pay too high premiums in the observed samples. Malmendier and Tate (2008) find an evidence that overconfident investors tend to make lower-quality acquisitions when the company has sufficient internal resources.

Acquisitions or mergers made for non-economic reasons may particularly result in a deal failure and value destruction. In order to decrease behavioural costs and agency costs, managers are disciplined by various corporate governance mechanisms - above all a board of directors (Fama and Jensen, 1983).

A prevailing board structure in the US is a unitary board, characterised by one board with executive and non-executive members. In contrast, a predominant structure in continental Europe is a dual board, which consists of an executive board and a supervisory board (Mallin, 2004). A supervisory board monitors the CEO, therefore, in this structure, there is a clear separation of management and control of decisions.

\subsection{Supervisory board as a governance mechanism}

The board has the ultimate responsibility for the smooth functioning of the firm by setting, choosing, dismissing and rewarding top managers, voting on major operational and financial decisions including M\&A and offering expert advice for the managers (Jensen, 1993). However, boards tend to fail in their effectiveness and responsiveness to problems in the companies. For instance, only a marginal part of the boards removes poor-performing CEOs, or if they do so, their actions are not timely (Jensen, 1993). Board failures result from several issues. First, board members seem to be too polite, thus, less critical and controlling. Second, the CEO decides to what extent inside information will be shared with the board. This information asymmetry limits the board's ability to fully and effectively monitor the CEO. Third, the members of the board often lack financial or managerial expertise and are unable to critically evaluate CEO's decision. Fourth, boards are frequently oversized thus ineffective and easily influenced by the CEO. Fifth, it is common that the CEO is also a chairman of the board, which substantially decreases the controlling power of the board.

The identified issues lower the board's effectiveness and increase managerial control, but, at the same time, implicate certain changes in the structure that can improve the board's performance. To raise independence of the board, the roles of the CEO and the chairman of the board should be separated, and the number of unaffiliated, independent board members increased. The board's effectiveness is also affected by its characteristics such as: gender ratio, ethnic diversity (Carter et al., 2010), board size (Huther, 1997; Eisenberg et al., 1998; Yermack, 1996), busyness of the board (Fich and Shivdasani, 2006), the qualifications and education of the board members (Fama, 1992), or the type of elections (Bebchuk and Cohen, 2005; Faleye, 2007; Kosnik, 1987).
Does the Structure of the Board of Directors Improve M\&A Performance? 
IJSR 7

Acting in the owners' interests, an effective board will approve only mergers and acquisitions that ultimately create value for shareholders, limiting the overinvestment problem and empire building desire of managers. Since the proper structure of the board influences the board performance, and an effective board controls and monitors the CEO better, the board structure should, therefore, affect M\&A performance.

\section{Methodology and data}

\subsection{Research methodology}

The most commonly adopted approach in the literature to examine the relation between the board characteristics and M\&A performance is an ordinary least squares regression (OLS), found in numerous studies such as: Byrd and Hickman (1992), Masulis et al. (2007), Moeller et al. (2004).

The model designed to test the hypotheses is presented by the following equation:

$$
\begin{aligned}
\text { CAR }_{i, t}=\alpha_{i}+ & \beta_{1} \text { CLASSIFIED }_{i}+\beta_{2} \text { SIZE }_{i}+\beta_{3} \text { INDEPENDENT }_{i}+\beta_{4} \text { DUALITY }_{i} \\
& +\beta_{5} \text { GENDER }_{i}+\sum_{j}^{n} \beta_{j} \text { CONTROL_VARIABLE }_{j}+\varepsilon_{i}
\end{aligned}
$$

The interpretation of the results is based on the coefficients of the variables in the regression model. The variables are discussed in the following subsections of the article.

\subsection{Independent variables - board structure}

\section{Classified board}

Nowadays, the prevailing structure among US firms is the classified board. The board is divided into separate classes, each elected once in a few year time. This means that the board cannot be fully replaced in a hostile takeover, thus such structure works as an antitakeover provision. There are two theories regarding how board classification influences the CEO and both of them are empirically supported by several papers. According to the first one, classified boards entrench the CEO and protect him from the market discipline, thus such companies undertake value-destroying acquisitions (Faleye, 2007; Bebchuk and Cohen, 2005; Masulis et al., 2007). The other one states that classification can encourage managers to invest in long-term projects by decreasing the takeover pressure (Stein, 1988). In the M\&A context, the managers could be reluctant to take up acquisitions that are dilutive, but value creative in the long-run. A positive influence of such a board is documented in studies of Cremers et al. (2017), whereas Daines et al. (2016) suggest that a classified board can supportively affect Tobin's $q$ for early-lifecycle firms.

As most of the recent studies support evidence that the staggered board positively influences a company's value and management choices the following hypothesis is formed: 


\section{Hypothesis 1: A classified board has a positive influence on the M\&A performance}

In empirical research papers, a classified system of the board is usually included in models as a binomial variable (Faleye, 2007; Masulis et al., 2007; Bebchuk and Cohen, 2005). Following mentioned studies, a dummy variable 'Classified' is created and is equal to ' 1 ' when the board is classified at the end of the year prior to the acquisition announcement and ' 0 ' otherwise.

\section{Board size}

Several papers examine the influence of board size on a company's performance. Lipton and Lorsch (1992) and Jensen (1993) criticize large boards as may face problems with communication or coordination of decision making. In a large group, the responsibility of the members is diluted, thus they may be less involved in the decision-making process. Furthermore, in a bigger group, a group conformity problem may become more apparent. The board members can feel uncomfortable to raise contradictory opinions and oppose the majority. Eisenberg et al. (1998) find an empirical evidence to support the hypothesis that large boards negatively affect a firm's performance. They show that companies with larger boards have lower industry-adjusted ROA. Similarly, Yermak (1995) and Faleye (2007) investigate US companies and find a negative relationship between the size of the board and Tobin's $q$. Masulis et al. (2007) conclude that the impact of the number of board members on 5-day bidder's CAR is statistically insignificant in the analyzed sample. To sum up, most of the studies document that the board size has a negative influence on the company's performance. Lack of efficiency in the decisionmaking process of the board may also influence M\&A decisions and therefore their performance, which leads to the following hypothesis:

\section{Hypothesis 2: The board size has a negative influence on the M\&A performance}

The variable 'Board size' is defined as the number of board members at the end of the year prior to the acquisition announcement.

\section{Independent directors}

The board's role is to represent and act in shareholders' interest. However, inside directors tend to be dependent on the top management and do not fulfil their controlling function efficiently. Boards with outside directors are found to be more responsive and more likely to dismiss the CEO in that case of poor performance. On the other hand, with inside directors, a board may benefit from more effective communication and cooperation (Vancil, 1987). The empirical research shows various evidence. Hermalin and Weisbach (1991) show no significant relation between board composition and company's performance measured as Tobin's $q$.

Byrd and Hickman (1992) examine the relation between the proportion of independent directors on board of acquiring companies and their abnormal returns around the day
Does the Structure of the Board of Directors Improve M\&A Performance? 
IJSR 7

of announcement of a tender offer. They find an evidence that if a company has more than $50 \%$ of independent outside directors, it has significantly higher abnormal returns around the announcement date. Miletkov et al. (2015) and Amar et al. (2011) investigate the relation between the percentage of independent board members and acquirer's 3-day $\mathrm{CAR}$ around the announcement date. They find an evidence that bidders with more independent members on board experience significantly higher abnormal returns. Based on findings from the aforementioned studies the following hypothesis is formed:

\section{Hypothesis 3: The ratio of independent directors on board has a positive influence on the M\&A performance}

The independence of the board is represented by a variable 'Independent' equal to the percentage of independent directors on the board.

\section{CEO duality}

The CEO of the company may also serve as a chairman of the board, which is a common practice in various companies. However, the controlling power of the board over the CEO is significantly lower and the board effectiveness decreases (Jensen, 1993). Furthermore, the board attention to monitoring is higher in the absence of CEO duality. The contrary theory is a stewardship model, according to which "the CEO wants to be a good steward of the corporation's assets" (Donaldson and Davis, 1991). Consequently, when the $\mathrm{CEO}$ is also appointed as the chairman, it might further motivate the $\mathrm{CEO}$ and improve his performance.

In line with the agency theory, a CEO duality is empirically shown to deteriorate company's performance measured as ROI, ROE and profit margin (Rechner and Dalton, 1991). However, some studies find an insignificant relation between the CEO duality and the company's performance measured by ROI (Boyd, 1995; Rechner and Dalton, 1991), ROE (Baliga et al., 1996; Rechner and Dalton, 1991), ROA (Baliga et al., 1996; Elsayed, 2007), Tobin's $q$ (Elsayed, 2007; Chen et al., 2008), profit margin (Rechner and Dalton, 1991).

CEO duality may also lower board's effectiveness as a corporate governance mechanism to prevent value-destroying mergers and acquisitions. Supporting empirical evidence is found in the paper of Masulis et al. (2007). Bidders with the CEO acting also as the board chairman experienced significantly lower returns around the announcement day. Given the results from the presented studies, the following hypothesis is stated:

\section{Hypothesis 4: The CEO duality has a negative influence on the M\&A performance}

In the model, CEO 'Duality' is defined as a dummy variable equal to ' 1 ' when the CEO was also a chairman of the board at the end of the year prior to the acquisition announcement and ' 0 ' otherwise. 


\section{Gender diversity}

A recent trend to promote gender equality in business has been also realised in the boards of companies. Apart from reputation concerns, diversity in a team leads to a broader range of perspectives, ideas and therefore improved performance (Lückerath-Rovers, 2011). Kramer et al. (2006) suggest when three or more women serve on the board, the decision-making process is more effective as the dynamic in the board is more open and collaborative and the perspectives of multiple stakeholders are brought into the discussion. Several papers find a positive influence of gender diversity on the company's performance measured as Tobin's $q$ (Sabatier, 2015), ROE (Lückerath-Rovers, 2013; Sabatier, 2015) and ROA (Sabatier, 2015). Studies of Ahern and Dittmar (2011) and Bøhren and Staubo (2013) document the opposite relation, however, in the context of parity gender law implementation. Following the results of empirical papers based on US samples, the hypothesis presented below is formulated:

\section{Hypothesis 5: A higher proportion of women serving on the board has a positive influence on the $M \& A$ performance}

Board diversity is defined as a percentage of female directors serving on the acquirer's board.

\subsection{Dependent variable - evaluation of $M \& A$ performance}

The measures of assessing M\&A performance are categorized under market measures, accounting measures and other measures (such as surveys of managers) (Bruner, 2004). The most popular measure used in research papers is an event study (short-term market measure) (Zollo and Meier, 2008). Furthermore, this method is used in studies evaluating the influence of board characteristics such as Byrd and Hickman (1992), Amar et al. (2011) or (Miletkov et al., 2015).

In the event study, actual returns on stocks of the acquirer over a short period of time around the deal announcement are compared to hypothetical returns in case of absence of an event. Cumulative abnormal return over the measurement window represents an increase or decrease in value of the acquirer as a result of the upcoming transaction. At the same time, it is assumed that the market can fully and correctly incorporate all new publicly available information is in stock prices. Consequently, the problem of joint hypothesis test occurs while assessing the performance of M\&A using this method (Binder, 1998).

The abnormal returns are estimated over a 3-day event window, as it is long enough to include most of the announcement effects and at the same time short enough not to capture reactions to other events. To check the robustness of the results, cumulative abnormal returns over a 5 -day $(-2,+2)$ and an 11-day $(-5,+5)$ event period are calculated.

The cumulative abnormal return is retrieved from the EVENTUS database. The tool calculates the CARs using the market model:

$$
C A R_{i, t}=\sum_{t=-1}^{1} R_{i, t}-\sum_{t=-1}^{1} E\left(R_{i, t}\right)
$$


where:

$R_{i, t}$ - the actual return on a given day,

$E\left(R_{i, t}\right)$ - the expected return based on CRSP Equally Weighted Market Index and estimated over the period $(-210,-11)$, where 0 is the announcement day.

\subsection{Control variables}

As bidder returns can be influenced by many factors, control variables are included in the regression model to ensure the robustness of the results. The variables include deal, bidder, and other corporate governance characteristics.

\section{Bidder characteristics}

Higher debt reduces free cash flows and limits the managerial empire building problem (Jensen, 1986). Leverage serves as a corporate governance mechanism, therefore, a debt ratio expressed as the book value of short- and long-term debt over the market value of total assets is expected to have a positive influence on CAR (Maloney et al., 1993).

According to Jensen (1986), if a firm generates excessive free cash flow, managers will over-expand the company and carry out value-destroying transactions. However, free cash flow can also indicate a good recent performance of the company. Hence, free cash flow might be either positively or negatively correlated with bidder's abnormal returns. In the study, FCF is calculated as operating income before depreciation less income taxes less interest expenses capital expenditures scaled by book value of total assets, in million USD.

As companies with higher Tobin's $q$ experience higher acquisition announcement abnormal returns, a variable 'Tobin's $q$ ' controlling for this phenomenon is included in the model and expressed as market value of equity plus book value of short- and longterm debt over book value of assets (Lang et al., 1991; Servaes, 1991). Chung and Pruitt (1994) find evidence that book value is a good approximation of the market value of debt when computing Tobin's $q$, therefore, book value of debt is used in calculations.

An acquisition of a large firm requires more resources from a potential bidder. The size of the firm is, therefore, an anti-takeover defence itself. Managers of large companies are more entrenched and can undertake value-destroying acquisitions, therefore, bidder size is expected to be negatively correlated with abnormal returns (Moeller et al., 2004). The firm size is measured as the logarithm of the book value of total assets in million USD.

\section{Deal characteristics}

Acquirers profit form a liquidity discount when buying private or subsidiary companies, which is supported by the studies of Officer (2007) and Koeplin et al. (2000). Abnormal returns of bidders in such transactions are significantly positive, whereas, when acquiring a public company, the abnormal returns are significantly negative. To capture this phenomenon, two dummy variables: private target 'Private' and a subsidiary target 'Subsidiary' are included.

According to the pecking order theory, the issue of equity signals overvaluation and the prices after the announcement are adjusted downwards The adverse selection problem 
is observed in mergers and acquisitions and bidders experience statistically significant negative abnormal returns when they pay with equity (Sarveas, 1991; Brown and Ryngaert, 1991). Dummy variables 'Stock' equal ' 1 ' for over $10 \%$-stock-financed deals and 'AllCash' equal to ' 1 ' for entirely cash-financed deals are included in the model.

Moeller et al. (2004) find that acquirer abnormal returns are higher when the deal size relative to bidder's market value of equity is greater. A relative deal size is computed as deal value over bidder's market equity value and is expected to have a positive influence on the bidder's abnormal return.

Further, a variable 'Industry' equal to 1 for the non-diversifying industry is created to control for lower announcement effects for diversifying acquisitions found by Morck et al. (1990).

\section{Corporate governance characteristics}

The interests of shareholders and managers should be aligned by equity ownership of the executives or equity-based executive compensation (Jensen, 1993). By such tools, managers are incentivized to undertake actions that will result in long-term value creation. Kroll et al. (2008), Shinn (1999) and Walters et al. (2007) find a positive relation between managerial ownership level and abnormal returns. Hence, a dummy variable 'CEO equity ownership' equal to the percentage of shares held by the CEO is included.

\subsection{Data collection}

First, the data that meet the following criteria:

1. Both the bidder and the target are US-based companies. The choice is motivated by the greater availability of data regarding board structure in the US as well as unitary board system which allows examining more board characteristics (CEO duality, board independence),

2. The acquirer is a public company. The filter is applied to ensure availability of stock prices and financial data of the bidder,

3. The acquisition announcement took place over the period 1 January $2008-31$ December 2017. The period is determined by the availability of data, especially in the ISS database, which provides data since 2007,

4. The acquisition is completed. As the research investigates the board influence on actual deal performance, unfinalized acquisitions are excluded from the sample,

5. The deal value exceeds USD 1 million. The market reaction to small transactions might be not significant and would bring noise into the analysis,

6. The acquirer controls less than $50 \%$ of the target's shares before the announcement and, as a result of the transaction, holds afterwards over $50 \%$ of the shares. Since it results in a control gain over the target firm, a significant market reaction is expected, unlike in the case of an acquisition of a small percentage of the shares,

7. All data needed to obtain the values of the independent variables is available. The criterion is necessary to correctly run the OLS regression, is retrieved from Thomson One, Eventus, Institutional Shareholder Platform (ISS) and Compustat databases. Application of the criteria and exclusion of so-called outliers resulted in the sample of 2,613 deals.
Does the

Structure

of the Board

of Directors

Improve M\&A

Performance? 
IJSR 7

Table 1.

Data sample overview

\subsection{Descriptive statistics}

The sample includes a similar number of acquisitions per year -181 to 308 . The average abnormal return is positive and rises from 2008 to peak in 2013 and declines afterwards. A possible explanation for the lower number of acquisitions and below average cumulative abnormal returns in 2008 and 2009 is reduced M\&A activity during the financial crisis in 2007-2009 (Alexandridis et al., 2012). A positive trend in the number of acquisitions, as well as CAR in the following years, might have resulted from anM\&A activity rebound after the crisis. Due to the visible differences in average cumulative abnormal returns among the years, the fixed-time effects are controlled for in the model.

\section{Data sample overview}

The table presents the most important characteristics of the deal by year. The average abnormal return was visibly higher in the years 2012-2014.

\begin{tabular}{lccccc}
\hline Year & Number of acquisitions & $\begin{array}{c}\text { Percentage of } \\
\text { sample }\end{array}$ & $\begin{array}{c}\text { Average 3-day } \\
\text { CAR }\end{array}$ & $\begin{array}{c}\text { Deal (median) in } \\
\text { million USD }\end{array}$ & $\begin{array}{c}\text { Relative size } \\
\text { (median) }\end{array}$ \\
\hline 2008 & 195 & $7 \%$ & $0.02 \%$ & 90 & $2.95 \%$ \\
\hline 2009 & 181 & $7 \%$ & $0.09 \%$ & 88 & $2.90 \%$ \\
\hline 2010 & 271 & $10 \%$ & $0.40 \%$ & 152 & $4.96 \%$ \\
\hline 2011 & 287 & $11 \%$ & $0.50 \%$ & 120 & $3.74 \%$ \\
\hline 2012 & 308 & $12 \%$ & $0.79 \%$ & 129 & $4.83 \%$ \\
\hline 2013 & 277 & $11 \%$ & $1.17 \%$ & 147 & $5.83 \%$ \\
\hline 2014 & 290 & $11 \%$ & $1.01 \%$ & 159 & $4.06 \%$ \\
\hline 2015 & 281 & $11 \%$ & $0.63 \%$ & 235 & $5.84 \%$ \\
\hline 2016 & 284 & $11 \%$ & $0.10 \%$ & 206 & $4.94 \%$ \\
\hline 2017 & 239 & $9 \%$ & $0.53 \%$ & 180 & $4.33 \%$ \\
\hline
\end{tabular}

Source: Author's own analysis.

The average abnormal return of $0.53 \%$ is slightly lower than the average return in the data sets of similar studies, which amounts to approximately 1\% (Amar et al., 2011; Masulis et al., 2007). The average CAR is significantly different from zero at the $1 \%$ significance level. The CAR for all-cash deals equals to $0.82 \%$ and is different from the CAR of the deals partially paid in stock at the 5\% significance level. The difference between the average abnormal return when announcing an acquisition of a public target and a private target is insignificant. An announcement of the acquisition of a subsidiary resulted on average in the $1.56 \%$ abnormal return and it was significantly higher than the CAR over the announcement period of an acquisition of a public or private subsidiary, which is similar to the differences documented in Moeller et al.(2003).

\section{Market reaction vs. deal characteristics}

The table presents the average abnormal return by specific deal characteristics. The number in the brackets is a p-value obtained in one-sample, two-sided t-test. ***, **, * stands for significance at the $1 \%, 5 \%$ and $10 \%$ level, respectively, 


\begin{tabular}{lcccccc}
\hline CAR (-1, 1) & $\begin{array}{c}\text { Whole sample } \\
(\mathbf{1})\end{array}$ & All Cash (2) & $\begin{array}{c}>\mathbf{1 0 \%} \text { of } \\
\text { Stock (3) }\end{array}$ & $\begin{array}{c}\text { Public target } \\
\mathbf{( 4 )}\end{array}$ & $\begin{array}{c}\text { Private target } \\
\mathbf{( 5 )}\end{array}$ & $\begin{array}{c}\text { Subsidiary } \\
\text { target (6) }\end{array}$ \\
\hline Mean & $\begin{array}{c}0.53 \% \\
(0.00)^{* * *}\end{array}$ & $\begin{array}{c}0.82 \% \\
(0.00)^{* * *}\end{array}$ & $\begin{array}{c}0.07 \% \\
(0.86)\end{array}$ & $\begin{array}{c}0.29 \% \\
(0.21)\end{array}$ & $\begin{array}{c}0.53 \% \\
(0.00)^{* * *}\end{array}$ & $\begin{array}{c}1.56 \% \\
(0.00)^{* * *}\end{array}$ \\
\hline $\begin{array}{l}\text { Number of } \\
\text { observations }\end{array}$ & 2,613 & 1,039 & 375 & 801 & 1,564 & 227 \\
\hline
\end{tabular}

\begin{tabular}{lcccc}
\hline CAR (-1,1) & \multicolumn{4}{c}{ Difference test } \\
\hline \multirow{2}{*}{ Difference } & Cash-Stock & Public-Private & Public-Subsidiary & Private-Subsidiary \\
& $(2)-(3)$ & $(4)-(5)$ & $(4)-(6)$ & $(5)-(6)$ \\
\hline & $0.75 \%$ & $-0.24 \%$ & $-1.27 \%$ & $-1.03 \%$ \\
& $(0.04)^{* *}$ & $(0.30)$ & $(0.00)^{* * *}$ & $(0.00)^{* * *}$ \\
\hline
\end{tabular}

Table 2.

Market reaction vs. deal characteristics

Source: Author's own analysis.

An average board in the sample is not-classified, consists of 9.31 board members, $79 \%$ of which are independent directors and $13 \%$ women. The CEO was also the chairman of the board of the acquiring company in $49 \%$ of the deals. The average acquirer had a leverage of 0.22 , free cash flow scaled by the firm size of 0.06 , Tobin's $q$ equal to 1.51 and logarithm of firm's assets to 3.6. The relative deal size amounts to $13 \%, 53 \%$ of targets operated in the same industry as the acquirers. $60 \%$ of the targets were private, and $9 \%$ subsidiary of the bidder. Out of all deals, $9 \%$ were paid fully in cash and $14 \%$ in at least $10 \%$ of the stock.

\section{Descriptive statistics}

\begin{tabular}{|c|c|c|c|c|c|c|c|c|c|}
\hline & Mean & St dev & Min & Q25 & Median & Q75 & Max & Skew & Kurt \\
\hline \multicolumn{10}{|c|}{ Dependent variable } \\
\hline $\operatorname{CAR}(-1,+1)$ & 0.01 & 0.05 & -0.40 & -0.01 & 0.00 & 0.02 & 0.52 & 0.35 & 13.03 \\
\hline \multicolumn{10}{|c|}{ Board structure variables } \\
\hline Classified & 0.41 & 0.49 & 0.00 & 0.00 & 0.00 & 1.00 & 1.00 & 0.38 & 1.15 \\
\hline Board size & 9.31 & 2.31 & 4.00 & 8.00 & 9.00 & 11.00 & 24.00 & 0.64 & 4.37 \\
\hline Independent & 0.79 & 0.11 & 0.37 & 0.71 & 0.80 & 0.88 & 1.00 & -0.97 & 4.75 \\
\hline Duality & 0.49 & 0.50 & 0.00 & 0.00 & 0.00 & 1.00 & 1.00 & 0.06 & 1.00 \\
\hline Diversity & 0.13 & 0.10 & 0.00 & 0.00 & 0.13 & 0.20 & 0.58 & 0.44 & 2.83 \\
\hline \multicolumn{10}{|c|}{ Control variables - firm characteristics } \\
\hline Leverage & 0.22 & 0.18 & 0.00 & 0.08 & 0.18 & 0.33 & 0.96 & 0.91 & 3.60 \\
\hline FCF & 0.06 & 0.07 & -0.70 & 0.01 & 0.06 & 0.10 & 0.54 & -0.86 & 14.54 \\
\hline Tobin's $q$ & 1.51 & 1.02 & 0.07 & 0.92 & 1.30 & 1.84 & 13.85 & 2.73 & 18.78 \\
\hline Firm size & 3.60 & 0.72 & 1.98 & 3.08 & 3.53 & 4.01 & 6.31 & 0.55 & 3.33 \\
\hline \multicolumn{10}{|c|}{ Control variables - deal characteristics } \\
\hline $\begin{array}{l}\text { Relative deal } \\
\text { size }\end{array}$ & 0.13 & 0.27 & 0.01 & 0.02 & 0.04 & 0.12 & 3.56 & 5.11 & 40.15 \\
\hline Industry & 0.53 & 0.50 & 0.00 & 0.00 & 1.00 & 1.00 & 1.00 & -0.13 & 1.02 \\
\hline Private & 0.60 & 0.49 & 0.00 & 0.00 & 1.00 & 1.00 & 1.00 & -0.40 & 1.16 \\
\hline
\end{tabular}

Table 3.

Descriptive statistics 
IJSR

7

Table 3.

Descriptive statistics

\begin{tabular}{|c|c|c|c|c|c|c|c|c|c|}
\hline & Mean & St dev & Min & Q25 & Median & Q75 & Max & Skew & Kurt \\
\hline Subsidiary & 0.09 & 0.28 & 0.00 & 0.00 & 0.00 & 0.00 & 1.00 & 2.93 & 9.61 \\
\hline All-Cash & 0.40 & 0.49 & 0.00 & 0.00 & 0.00 & 1.00 & 1.00 & 0.42 & 1.18 \\
\hline Stock & 0.14 & 0.35 & 0.00 & 0.00 & 0.00 & 0.00 & 1.00 & 2.03 & 5.14 \\
\hline \multicolumn{10}{|c|}{ Control variable - other corporate governance characteristics } \\
\hline $\begin{array}{l}\text { CEO } \\
\text { ownership }\end{array}$ & 0.01 & 0.01 & 0.00 & 0.00 & 0.00 & 0.01 & 0.16 & 6.80 & 83.18 \\
\hline
\end{tabular}

Source: Author's own analysis.

\section{Results}

\subsection{Research findings}

An OLS regression is run to test the hypotheses stated in the research, the results of which are shown in Table 4. The second model controls for the fixed-time effects, which were included due to significant differences in cumulative abnormal returns in every year of the analyzed period. Two out of five board characteristics turn out to significantly influence the acquirer returns.

All else equal, board classification has a positive influence on the acquirer returns, at the 5\% significance level in the first and at the $1 \%$ level in the second model, which confirms the hypothesis 1 and findings in the most recent papers (Cremers et al., 2017; Daines et al., 2016). The result is inconsistent with the theory that classified boards entrench managers but supports the theory that a classified board can lower a takeover pressure and encourage managers to pursue deals that create value in a long-term perspective rather than improve profitability or EPS in the short-run (Stein, 1988).

The independence of the board is significant at the $10 \%$ significance level and the coefficient equals to 0.0176 , which supports the hypothesis 3 , predicting a positive influence of the ratio of independent directors on board on the acquirer returns. The results allow presuming that independent directors more effectively monitor the management, lowering agency and behavioural costs that lead to value-destroying acquisitions.

The variable board size, CEO duality and gender diversity are insignificant at every significance level. The majority of control variables has a significant impact on the acquirer returns and the coefficient signs are similar to previously stated research predictions based on the related studies such as Moeller et al. (2004) or Masulis et al. (2007). Free cash flow, relative deal size, subsidiary target and cash deal have a significantly positive effect on the acquirer abnormal returns. The variables firm size, stock payment, and surprisingly, Tobin's $q$ have a negative impact on the bidder CAR.

The model without and with fixed-time effect explains respectively $2.87 \%$ and $3.32 \%$ of the acquirer abnormal returns. As the White test indicated, heteroskedasticity of standard errors in the regression, which can result in a misleading interpretation of the results an option "robust" available in the STATA program is used. The results of the regression account for heteroskedasticity by increasing standard errors that are positively correlated with the variables, therefore, more evidence is needed to reject the null hypothesis. The degree of multicollinearity between the independent variables is small - the mean amounts to 1.39 in the model without fixed-time effects and 1.70 in 
the model with the fixed time effects. The value is below the suggested cut-off of 10 by Hair et al. (1998).

\section{OLS regiression results}

Table 4 presents the average abnormal return by specific deal characteristics. The number in the brackets is a p-value obtained in one-sample, two-sided t-test. ***, **, * stands for significance at the $1 \%, 5 \%$ and $10 \%$ level, respectively. The OLS regression is run with the option "robust", which considers heteroskedasticity of the model.

\begin{tabular}{|c|c|c|}
\hline $\operatorname{CAR}(-1,+1)$ & Model 1, robust & Model 2, robust \\
\hline Classified & $0.0055(0.02)^{* *}$ & $0.0060(0.01)^{* * *}$ \\
\hline Board size & $-0.0003(0.57)$ & $-0.0002(0.62)$ \\
\hline Independent & $0.0176(0.08)^{*}$ & $0.0173(0.09)^{*}$ \\
\hline Duality & $-0.0015(0.46)$ & $-0.0012(0.59)$ \\
\hline Diversity & $-0.0170(0.16)$ & $-0.0185(0.12)$ \\
\hline Leverage & $0.0043(0.59)$ & $0.0035(0.67)$ \\
\hline FCF & $0.0452(0.04)^{* *}$ & $0.0479(0.03)^{* *}$ \\
\hline Tobin's $q$ & $-0.0020(0.14)$ & $-0.0021(0.14)$ \\
\hline Firm size & $-0.0035(0.06)^{*}$ & $-0.0035(0.06)^{*}$ \\
\hline Relative deal size & $0.0157(0.04)^{* *}$ & $0.0153(0.04)^{* *}$ \\
\hline Industry & $0.0029(0.16)$ & $0.0030(0.16)$ \\
\hline Private & $0.0033(0.19)$ & $0.0027(0.27)$ \\
\hline Subsidiary & $0.0124(0.00)^{* * *}$ & $0.0114(0.00)^{* * *}$ \\
\hline All-Cash & $0.0041(0.06)^{*}$ & $0.0036(0.10)^{*}$ \\
\hline Stock & $-0.0069(0.10)^{*}$ & $-0.0075(0.07)^{*}$ \\
\hline CEO Shares & $0.1205(0.23)$ & $0.1181(0.24)$ \\
\hline Intercept & $-0.0009(0.93)$ & $-0.0054(0.64)$ \\
\hline Time-fixed effects & $x$ & $\checkmark$ \\
\hline F-statistics & 0.00 & 0.00 \\
\hline R-squared & $2.87 \%$ & $3.32 \%$ \\
\hline Mean VIF & 1.39 & 1.70 \\
\hline
\end{tabular}

Source: Author's own analysis.

\subsection{Robustness check}

The results are robust to several other specifications of the empirical tests: (i) the regression is run measuring the acquirer returns in 5-day and 11-day event Windows with the fixed-time effects; (ii) only deals that relative deal value falls in the interval of $1-100 \%$ are included, as extreme values may disrupt the results of the analysis; (iii) the regression with alternative methods used to measure board characteristics is performed. In separate OLS regressions size of the board is measured as a logarithm of board members, gender diversity as a dummy equal to one if the board has at least three women, board independence as a binomial variable equal to one if the percentage of independent directors equals or exceeds the mean, (iv) the significance of intercorrelation of the two
Does the Structure of the Board of Directors Improve M\&A Performance?
Table 4.

OLS regression results 
IJSR 7

variables is checked by adding a variable equal to the product of board size and firm size into the regression. The new variable, as well as board size, are insignificant on all levels, whereas firm size remains significant at the $10 \%$ level, meaning that the firm size, unlike the board size, has an actual influence on the acquirer returns.

\section{Does the board structure matter?}

Research shows acquisitions on average destroy, rather than create value for bidders. Deal failure and value destruction particularly occur when a deal is pursued because of non-economic reasons: managerial overconfidence and hubris as well as agency issues. In order to limit such investments, companies need effective boards. The evidence is found that board independence and classification significantly and positively influence bidders value. Independent and classified boards monitor the CEO better and shift the focus of the $\mathrm{CEO}$ to the long-term perspective in terms of value creation for shareholders.

The outcome of this study can be of interest of lawmakers, but above all, various acquisitive and non-acquisitive companies by aiding them in finding an optimal board structure, which can fulfil their monitoring duties more effectively, leading to profitable investment decisions, especially those relating to mergers and acquisitions. The trade-off between the costs and benefits of adjusting the board structure differs among the firms and depends on numerous factors, one of them being, as an example, the overall costs of implementing changes. Although the outcomes of this study are quite straightforward, the decisions regarding adjustments to the board structure should be reviewed by each company individually.

\section{References}

Ahern, K.R., and Dittmar, A.K. (2012), "The changing of the boards: The impact on firm valuation of mandated female board representation", The Quarterly Journal of Economics, vol. 127, no. 1, pp. 137-197, https://doi.org/10.1093/qje/qjr049.

Alexandridis, G., Mavrovitis, C.F., and Travlos, N.G. (2012), "How have M\&As changed? Evidence from the sixth merger wave", The European Journal of Finance, vol. 18, no. 8, pp. 663-688.

Amar, W.B., Boujenoui, A., and Francoeur, C. (2011), "CEO attributes, board composition, and acquirer value creation: A Canadian study", Canadian Journal of Administrative Sciences / Revue Canadienne des Sciences de l'Administration, vol. 28, no. 4, pp. 480-492, https://doi. org/10.1002/cjas.223.

Baliga, B.R., Moyer, R.C., and Rao, R.S. (1996), "CEO duality and firm performance: What's the fuss?", Strategic Management Journal, vol. 17, no. 1, pp. 41-53.

Bebchuk, L.A., Cohen, A. (2005), "The costs of entrenched boards", Journal of Financial Economics, vol. 78, no. 2, pp. 409-433, https://doi.org/10.3386/w10587.

Binder, J. (1998), "The event study methodology since 1969", Review of Quantitative Finance and Accounting, vol. 11, no. 2, pp. 111-137, https://doi.org/10.1023/A:1008295500105.

Bøhren, Ø., and Staubo, S. (2014), "Does mandatory gender balance work? Changing organizational form to avoid board upheaval", Journal of Corporate Finance, vol. 28, pp. 152-168, https:// doi.org/10.1016/j.jcorpfin.2013.12.005.

Boyd, B.K. (1995), "CEO duality and firm performance: A contingency model”, Strategic Management Journal, vol. 16, no. 4, pp. 301-312, https://doi.org/10.1002/smj.4250160404.

Brown, D.T., and Ryngaert, M.D. (1991), "The mode of acquisition in takeovers: Taxes and asymmetric information", The Journal of Finance, vol. 46, no. 2, pp. 653-669, https://doi. org/10.1111/j.1540-6261.1991.tb02678.x. 
Bruner, R.F. (2004), Applied Mergers and Acquisitions, Vol. 173, John Wiley \& Sons, New York. Byrd, J.W., and Hickman, K.A. (1992), "Do outside directors monitor managers?: Evidence from tender offer bids", Journal of Financial Economics, vol. 32, no. 2, pp. 195-221, https://doi. org/0.1016/0304-405X(92)90018-S.

Carter, D.A., D'Souza, F., Simkins, B.J., and Simpson, W.G. (2010), "The gender and ethnic diversity of US boards and board committees and firm financial performance", Corporate Governance: An International Review, vol. 18, no. 5, pp. 396-414, https://doi.org/10.1111/ j.1467-8683.2010.00809.x.

Chen, C.W., Lin, J.B., and Yi, B. (2008), "CEO duality and firm performance: An endogenous issue", Corporate Ownership and Control, vol. 6, no. 1, pp. 58-65, https://doi.org/10.22495/cocv6ilp6.

Chung, K.H., and Pruitt, S.W. (1994), “A simple approximation of Tobin's q", Financial Management, vol. 23, no. 3, pp. 70-74, https://doi.org/10.2307/3665623.

Cremers, K.M., Litov, L.P., and Sepe, S.M. (2017), "Staggered boards and long-term firm value, revisited", Journal of Financial Economics, vol. 126, no. 2, pp. 422-444, https://doi. org/10.1016/j.jfineco.2017.08.003.

Daines, R., Li, S.X., and Wang, C.C. (2016), Can staggered boards improve value? Evidence from the Massachusetts natural experiment, working paper, available at: http://www.ecgi.global (accessed: 8 May 2018).

Donaldson, L., and Davis, J.H. (1991), "Stewardship theory or agency theory: CEO governance and shareholder returns", Australian Journal of Management, vol. 16, no. 1, pp. 49-64, https:// doi.org/10.1177/031289629101600103.

Eisenberg, T., Sundgren, S., and Wells, M.T. (1998), "Larger board size and decreasing firm value in small firms", Journal of Financial Economics, vol. 48, no. 1, pp. 35-54, https://doi. org/10.1016/S0304-405X(98)00003-8.

Elsayed, K. (2007), "Does CEO duality really affect corporate performance?", Corporate Governance: An International Review, vol. 15, no. 6, pp. 1203-1214, https://doi.org/10.1111/ j.1467-8683.2007.00641.x.

Faleye, O. (2007), "Classified boards, firm value, and managerial entrenchment", Journal of Financial Economics, vol. 83, no. 2, pp. 501-529, https://doi.org/10.1016/j.jineco.2006.01.005.

Fama E.F., and Jensen, M.C. (1983), "Separation of ownership and control", Journal of Law and Economics, vol. 26, no. 2, pp. 301-325, https://doi.org/10.1086/467037.

Fich, E.M., and Shivdasani, A. (2006), "Are busy boards effective monitors?", Journal of Finance, vol. 61, no. 2, pp. 689-724, https://doi.org/10.1111/j.1540-6261.2006.00852.x.

Hair, J.F., Black, W.C., Babin, B.J., Anderson, R.E., and Tatham, R.L. (1998), Multivariate Data Analysis (vol. 5, no. 3), Prentice Hall, Upper Saddle River, NJ, pp. 207-219.

Hermalin, B.E., and Weisbach, M.S. (1991), "The effects of board composition and direct incentives on firm performance", Financial Management, vol. 20, no. 4, pp. 101-112, https://doi. org/10.5539/ijbm.v9n8p170.

Huther, J. (1997), "An empirical test of the effect of board size on firm efficiency", Economics Letters, vol. 54, no. 3, pp. 259-264, https://doi.org/10.1016/S0165-1765(97)00035-9.

Jensen, M., and Meckling, W. (1976), "Theory of the Firm: Managerial Behavior, Agency Costs and Ownership Structure", Journal of Financial Economics, vol. 3, no. 4, pp. 305-360, https:// doi.org/10.1016/0304-405X(76)90026-X.

Jensen, M.C. (1986), "Agency costs of free cash flow, corporate finance, and takeovers", The American Economic Review, vol. 76, no. 2, pp. 323-329, https://doi.org/10.2139/ssrn.99580.

Jensen, M.C. (1993), "The modern industrial revolution, exit, and the failure of internal control systems", Journal of Finance, vol. 48, no. 3, pp. 831-880, https://doi.org/10.2307/2329018.

Koeplin, J., Sarin, A., and Shapiro, A.C. (2000), "The private company discount", Journal of Applied Corporate Finance, vol. 12, no. 4, pp. 94-101, https://doi.org/10.1111/j.1745-6622.2000. tb00022.x.
Does the

Structure of the Board of Directors Improve M\&A Performance? 
IJSR 7

Kosnik, R.D. (1987), "Greenmail: A study of board performance in corporate governance", Administrative Science Quarterly, vol. 32, no. 2, pp. 163-185, https://doi.org/10.2307/2393124.

Kramer, V.W., Konrad, A.M., Erkut, S., and Hooper, M.J. (2006), "Critical mass on corporate boards: Why three or more women enhance governance", Organizational Dynamics, vol. 37, no. 2, pp. 2-4, https://doi.org/10.1016/j.orgdyn.2008.02.005.

Kroll, M., Walters, B.A., and Wright, P. (2008), "Board vigilance, director experience, and corporate outcomes", Strategic Management Journal, vol. 29, no. 4, pp. 363-382, https://doi.org/10.1002/ smj.649.

Lang, L.H., Stulz, R., and Walkling, R.A. (1991), "A test of the free cash flow hypothesis: The case of bidder returns", Journal of Financial Economics, vol. 29, no. 2, pp. 315-335, https://doi. org/10.1016/0304-405X(91)90005-5.

Lipton, M., and Lorsch, J.W. (1992), "A modest proposal for improved corporate governance”, The Business Lawyer, vol. 48, no. 1, pp. 59-77, https://doi.org/10.12691/jfa-5-3-4.

Lückerath-Rovers, M. (2011), "Women on boards and firm performance", Journal of Management \& Governance, vol. 17, no. 2, pp. 491-509, https://doi.org/10.1007/s10997-011-9186-1.

Malatesta, P.H. (1983), "The wealth effect of merger activity and the objective functions of merging firms", Journal of Financial Economics, vol. 11, no. 1-4, pp. 155-181, https://doi. org/10.1016/0304-405X(83)90009-0.

Mallin, C.A. (2004), Corporate Governance, Oxford University Press, Oxford, UK, pp. 161-179.

Malmendier, U., and Tate, G. (2008), "Who makes acquisitions? CEO overconfidence and the market's reaction", Journal of Financial Economics, vol. 89, no. 1, pp. 20-43, https://doi.org/10.1016/j. jfineco.2007.07.002.

Maloney, M.T., McCormick, R.E., and Mitchell, M.L. (1993), "Managerial decision making and capital structure", Journal of Business, vol. 66, no. 2, pp. 189-217, https://doi.org/10.1086/296601.

Masulis, R.W., Wang, C., and Xie, F. (2007), "Corporate governance and acquirer returns", Journal of Finance, vol. 62, no. 4, pp. 1851-1889, https://doi.org/10.1111/j.1540-6261.2007.01259.x.

Miletkov, M., Moskalev, S., and Wintoki, M.B. (2015), "Corporate boards and acquirer returns: international evidence”, Managerial Finance, vol. 41, no. 3, pp. 244-266, https://doi.org/10.1108/ MF-03-2014-0063.

Moeller, S.B., Schlingemann, F.P., and Stulz, R.M. (2004), "Firm size and the gains from acquisitions", Journal of Financial Economics, vol. 73, no. 2, pp. 201-228, https://doi.org/10.1016/j. jfineco.2003.07.002.

Morck, R., Shleifer, A., and Vishny, R.W., (1990), “Do managerial objectives drive bad acquisitions?", Journal of Finance, vol. 45, no. 1, pp. 31-48, https://doi.org/10.2307/2328808.

Officer, M.S. (2007), "The price of corporate liquidity: Acquisition discounts for unlisted targets", Journal of Financial Economics, vol. 83, no. 3, pp. 571-598, https://doi.org/10.1016/j. jfineco.2006.01.004.

Rechner, P.L., and Dalton, D.R. (1991), "CEO duality and organizational performance: A longitudinal analysis", Strategic Management Journal, vol. 12, no. 2, pp. 155-160, https://doi.org/10.1002/ smj.4250120206.

Roll, R. (1986), "The hubris hypothesis of corporate takeovers", Journal of Business, vol. 59, no. 2 , pp. 197-216, https://doi.org/10.1086/296325.

Sabatier, M. (2015), "A women's boom in the boardroom: effects on performance?", Applied Economics, vol. 47, no. 26, pp. 2717-2727, https://doi.org/10.1080/00036846.2015.1008774.

Servaes, H. (1991), "Tobin's $q$ and the gains from takeovers", Journal of Finance, vol. 46, no. 1, pp. 409-419, https://doi.org/10.1111/j.1540-6261.1991.tb03758.x.

Shinn, E.W. (1999), "Returns to acquiring firms: The role of managerial ownership, managerial wealth, and outside owners", Journal of Economics and Finance, vol. 23, no. 1, pp. 78-89, https://doi.org/10.1007/BF02752689. 
Stein, J.C. (1988), “Takeover threats and managerial myopia”, Journal of Political Economy, vol. 96, no. 1, pp. 61-80, https://doi.org/10.1086/261524.

Vancil, R.F. (1987), Passing the Baton: Managing the Process of CEO Succession, Harvard Business School, Boston, https://doi.org/10.1002/hrm.3930270210.

Walters, B.A., Kroll, M.J., and Wright, P. (2007), "CEO tenure, boards of directors, and acquisition performance", Journal of Business Research, vol. 60, no. 4, pp. 331-338, https://doi. org/10.1016/j.jbusres.2006.12.001.

Yermack, D. (1996), "Higher market valuation of companies with a small board of directors", Journal of Financial Economics, vol. 40, no. 2, pp. 185-211, https://doi.org/10.1016/0304405X(95)00844-5.

Zollo, M., and Meier, D. (2008), "What is M\&A performance?", The Academy of Management Perspectives, vol. 22, no. 3, pp. 55-77, https://doi.org/10.5465/amp.2008.34587995.
Does the Structure of the Board of Directors Improve M\&A Performance? 